\title{
Feeding, growth and survival of juvenile summer flounder Paralichthys dentatus: experimental analysis of the effects of temperature and salinity
}

\author{
Kirk D. Malloy, Timothy E. Targett \\ University of Delaware, College of Marine Studies, Lewes, Delaware 19958, USA
}

\begin{abstract}
Laboratory experiments were conducted on juvenile summer flounder Paralichthys dentatus (41 to $80 \mathrm{~mm}$ total length) to determine low temperature tolerance $\left(2\right.$ to $3^{\circ} \mathrm{C}$ ) at 10,20 , and $30 \%$ salinity, and to measure feeding rate, assimilation efficiency, growth rate and growth efficiency at $2,6,10,14,18^{\circ} \mathrm{C}$ and 10,20 and $30 \%$ salinity. There was $100 \%$ survival at temperatures above $3^{\circ} \mathrm{C}$, suggesting that juvenile summer flounder are able to survive most winter water temperatures encountered in north/central Mid-Atlantic Bight (MAB) estuaries. Mortality was $42 \%$ after $16 \mathrm{~d}$ at 2 to $3{ }^{\circ} \mathrm{C}$. and was highest in fish $<50 \mathrm{~mm}$ TL $(1 \mathrm{~g})$. Mean specific growth rates were not significantly different between 2 and $10^{\circ} \mathrm{C}$ (mean $=0.14 \% \mathrm{~d}^{-1}$ ), and these rates were not significantly different from zero. Mean growth rate increased to $2.4 \% \mathrm{~d}^{-1}$ at $14{ }^{\circ} \mathrm{C}$ and $3.8 \% \mathrm{~d}^{-1}$ at $18{ }^{\circ} \mathrm{C}$. Ad libitum feeding rate showed a similar relationship to temperature. Mean assimilation efficiency $(60.1 \%)$ was not affected by temperature. Mean growth efficiency $\left(K_{1}\right)$ was significantly lower at $6^{\circ} \mathrm{C}(-23.1 \%)$ than at 14 and $18^{\circ} \mathrm{C}$ (18.4 and $22.1 \%$, respectively), and was highly variable. Salinity had no significant effect on any parameters measured, suggesting that factors other than salinity are controlling spatial distributions. Mortality resulting from acute exposure to low temperature probably occurs during one 2 to 4 wk period each winter Recruitment success from north/central MAB estuaries may be lower in years with late winter cold periods (i.e. March vs December) due to increased numbers of fish being exposed to lethal low temperatures. Additional mortality probably results from low growth rates caused by sub-optimal temperatures (i.e. $<10^{\circ} \mathrm{C}$ ) throughout the spring. The annual contribution of new recruits from northern estuaries appears to be dependent on winter temperature regime, particularly on the magnitude and timing of temperature minima.
\end{abstract}

\section{INTRODUCTION}

Recruitment variability in fishes is considered to be a major cause of fluctuations in adult population size (Hunter 1976, Sissenwine 1984, Houde 1987). Small changes in mortality rates of early stages may have large effects on the subsequent size of adult populations (May 1974, Houde 1989), and factors influencing the relatively high mortality of early life history stages have the greatest effect on recruitment success (Houde 1987). Although much research has been done on predation and starvation in early larval stages (see Houde 1987), there is increasing evidence that mortality of late-larval/early-juvenile stages is an important contributor to year-class strength (Hunter 1976, Smith 1985, Folkvord \& Hunter 1986, Bailey \& Houde 1989). Since vulnerability to predation is size-dependent (Folkvord \& Hunter 1986, Van der Veer \& Bergman
1987, Bailey \& Houde 1989), slow growth during the critical larval-early juvenile period, resulting from suboptimal environmental conditions such as low temperature, may extend the period during which young fish are vulnerable to predation (Houde 1987).

Temperature is a dominant abiotic factor controlling feeding and growth (Brett 1979), and conditions at the extremes of an organism's tolerance range exert the greatest limitations on scope for growth (Warren \& Davis 1967. Weatherley \& Gill 1987). Temperatures outside an optimum range have deleterious effects on early growth in many species (Holt et al. 1981, Houde \& Taniguchi 1981, Taniguchi 1981, 1982, Cech \& Mitchell 1984, Lee et al. 1984, McMullen \& Middaugh 1985). Low temperatures experienced by larvae/juveniles in species spawning in winter can reduce ingestion rates, and, although maintenance requirements and activity may be lower, often result in reduced or negative 
growth. For example, winter temperature minima have been found to be significantly related to year-class strength in striped bass Morone saxatilis (Uphoff 1989), cod Gadus morhua (Brown et al. 1989) and herring Clupea harengus (Stocker \& Haist 1984, Anthony \& Fogarty 1985)

Salinity is also known to affect growth and survival of young fishes, particularly metamorphosing juveniles (Houde \& Taniguchi 1979, DeSilva \& Perera 1984). Energetic demands of osmoregulation at extremely high or low salinities may reduce the energy available for growth (Kinne 1960, Brett 1979). Significant interactions between temperature and salinity effects on growth rates have also been found (Kinne 1960). An understanding of the environmental factors which influence feeding, growth and survival of young fishes is important to understanding the mechanisms and processes underlying recruitment variability and fluctuations in year-class strength.

Summer flounder Paralichthys dentatus occur in estuarine and continental shelf waters from Nova Scotia to the Atlantic coast of south Florida (Poole 1966 , Rogers \& Van Den Avyle 1983). Abundance is greatest in the Mid-Atlantic Bight (MAB), between Cape Cod and Cape Hatteras, where this species supports one of the most important commercial and recreational fisheries (Mid-Atlantic Fishery Management Council 1988). Adults spawn over a protracted period while migrating offshore to deeper ( 30 to $200 \mathrm{~m}$ ) shelf waters for the winter (Rogers \& Van Den Avyle 1983). Spawning occurs from September through January in the $\mathrm{MAB}$, and from November through February in the South Atlantic Bight (SAB) (Smith 1973, Poole 1966). Larvae are transported inshore, and in the MAB metamorphosing post-larvae (10 to $14 \mathrm{~mm} \mathrm{TL}$ ) enter estuaries and bays from October to May (Rogers \& Van Den Avyle 1983, Able et al. 1990). Newly settled juveniles remain in nursery areas until the following fall, and are most common on muddy substrates at salinities $>12 \%$ (Powell \& Schwartz 1977, Wyanski 1988).

The abundance of juvenile summer flounder reported in Chesapeake Bay, the bays of Virginia's eastern shore and the sounds of North Carolina have led to the view that these are the most important nursery areas (Deubler 1958, Pearcy \& Richards 1962, Murawski 1970). However, important spawning grounds appear to be located off New York and New Jersey and as far north as Massachusetts (Smith 1973, Able et al. 1990), and there is increasing evidence that estuaries in the northern part of this species' range (north/central MAB; i.e. Delaware, New Jersey) are more important nursery grounds than previously thought (Able et al. 1990, Szedlmayer et al. in press).

Since immigration of young summer flounder into estuarine nurseries occurs from fall through early spring, exposure to low winter temperatures in north/ central MAB estuaries may affect feeding, growth and survival of early juveniles. Bottom temperatures as low as $0^{\circ} \mathrm{C}$ are common in Delaware Bay (see Daiber et al. 1975), and thus may affect survival of young summer flounder near the northern extent of their range. Little is known about the effects of abiotic environmental variables on feeding, growth and mortality of early juvenile summer flounder. The only data available on the effects of temperature and salinity on growth are from Peters \& Angelovic (1971) on juveniles from North Carolina. Their data suggest that temperature has a significant effect on growth rate, but most test temperatures were 20 to $30^{\circ} \mathrm{C}$, much higher than would be encountered in estuaries of the $\mathrm{MAB}$ during winter. Peters \& Angelovic (1971) reported a trend of increased growth rates at higher salinities up to $30 \%$, but test salinities were generally $>20 \%$. Deubler \& White (1962) reported data suggesting higher growth rates at high salinities from 10 to $30 \%$.

The objectives of this research were to determine: (1) low temperature tolerance of juvenile summer flounder at 10,20 and $30 \%$ salinity; and (2) feeding rate, assimilation efficiency, growth rate and growth efficiency of juvenile summer flounder at $2,6,10,14,18^{\circ} \mathrm{C}$ and 10 , 20 , and $30 \%$. An understanding of the effects of temperature and salinity on early feeding, growth and survival will permit assessment of the potential impact of inter-annual variations in seasonal temperatures and salinity patterns on survival, and potentially recruitment success, of early juvenile summer flounder. Additionally, this information will help delineate areas that function as important juvenile summer flounder nursery grounds on small scales (within estuaries) and large scales (coastwide).

\section{MATERIALS AND METHODS}

Post-larval summer flounder were collected in $1 \mathrm{~m}$ plankton nets ( $1 \mathrm{~mm}$ mesh) fished during night-time flood tides near Roosevelt Inlet, Delaware USA, every 7 to $10 \mathrm{~d}$ from November 1989 through April 1990. Nets were set for ca $4 \mathrm{~h}$ periods and checked at 20 to $60 \mathrm{~min}$ intervals

Newly settled juvenile summer flounder used in laboratory experiments were collected over a standard area from Indian River Bay, Delaware $\left(38^{\circ} 40^{\prime} \mathrm{N}\right.$, $75^{\circ} 05^{\prime} \mathrm{W}$ ) using a $10 \mathrm{~m}$ bag seine ( $5 \mathrm{~mm}$ mesh) with a chain attached to the lead line. Sampling was conducted at least every 7 to $10 \mathrm{~d}$ from February through June 1989 and 1990. Fish were returned to the laboratory and maintained in recirculating seawater trays at 8 to $10^{\circ} \mathrm{C}$ and $30 \%$, and were fed frozen mysid shrimp Neomysis americana caught locally (Schwartz 1980). 
Two recording temperature probes were deployed during winter 1989-1990 to measure in situ bottom temperatures in juvenile nursery grounds. One probe was located at our seining location in Indian River Bay, Delaware (water depth ca 0.5 to $1.5 \mathrm{~m}$ ), and another was located at the mouth of a tidal creek off Great Bay, New Jersey, where juvenile summer flounder are known to occur (water depth ca $2 \mathrm{~m}$ ).

Juvenile summer flounder used in all experiments were 41 to $80 \mathrm{~mm}$ total length (TL) $(0.7$ to $3.0 \mathrm{~g}$ wet weight), and mean initial weights did not differ significantly among treatments (ANOVA, $p>0.05$ ). All experiments were conducted in a temperature- and photoperiod-controlled room maintained on a $12 \mathrm{~h}$ light: $12 \mathrm{~h}$ dark photoperiod. Fish were held individually in clear polycarbonate containers (5.5 l), in 3 separate recirculating seawater systems (350 l each). Trays holding these containers were lined with black plastic to facilitate removal of uneaten food, and because dark backgrounds have been shown to optimize feeding in young flatfishes (Shelbourne 1964, White \& Stickney 1973). Each system was maintained at one of the 3 test salinites $(10,20$ or $30 \%)$.

A low-temperature tolerance experiment was run to estimate the lower lethal temperature of early juveniles ( 25 to $80 \mathrm{~mm} \mathrm{TL}$ ). Survival of 36 fish (12 at each salinity) was observed while the temperature was lowered from 10 to $2{ }^{\circ} \mathrm{C}$ at a rate of $0.3^{\circ} \mathrm{C} \mathrm{d}^{-1}$. Fish were then held at 2 to $2.4^{\circ} \mathrm{C}$ for $16 \mathrm{~d}$, and were fed ad libitum throughout the experiment. $\chi^{2}$ analysis was used to test the effect of salinity on mortality. To examine the tolerance of larger fish, an identical low temperature tolerance experiment was run at $2{ }^{\circ} \mathrm{C}(30 \%)$ with 11 larger juveniles ( 3 to $6 \mathrm{~g}, 65$ to $90 \mathrm{~mm} \mathrm{TL}$ ).

Five feeding/growth experiments were run, each at a different temperature $\left(2,6,10,14,18^{\circ} \mathrm{C}\right)$, with $30 \mathrm{fish}$ in each experiment ( 10 at each salinity). Examining all combinations of temperature and salinity made it possible to detect interaction between these 2 factors. Fish were acclimated to temperature conditions for $\geq 2 \mathrm{wk}$, and were held in the $5.5 \mathrm{l}$ containers at test salinities for at least $1 \mathrm{wk}$ before each experiment. Prior to each experiment, food was withheld for $24 \mathrm{~h}$, and each fish was weighed to the nearest $\mathrm{mg}$ on a seawater-dampened sponge and measured to the nearest $\mathrm{mm}$ (TL).

Each fish was fed an excess of pre-weighed mysid shrimp (thawed and blotted dry before weighing) at the beginning of each day. Fish readily fed on the mysids. The following day, uneaten shrimp were collected from each container, blotted and weighed wet (mg), dried at $60^{\circ} \mathrm{C}$ for at least $24 \mathrm{~h}$, and weighed dry (mg). Retrieval of mysids added to empty containers resulted in losses of $<5 \%$ by weight. Therefore, unretrieved mysids were presumed to be an accurate measure of feeding. Experiments lasted for $10 \mathrm{~d}$. During this time, fecal material was collected from each fish's container with a pipette, blotted, and dried at $60^{\circ} \mathrm{C}$ for at least $24 \mathrm{~h}$. Fecal material and a sample of dried mysids were combusted at $450^{\circ} \mathrm{C}$ for $24 \mathrm{~h}$ to determine ash and organic content. This information was used to calculate total and organic assimilation efficiencies, as well as organic feeding rates. The wet weight ( $w w) / d r y$ weight $(d w)$ ratio of mysids was used to calculate $d w$ feeding rates. Feeding rates were also determined in terms of energy by analyzing energy content of mysids with a micro-bomb calorimeter (Phillipson 1964).

After 10 feeding days, food was withheld for $24 \mathrm{~h}$ and the fish were re-measured and re-weighed to determine growth rate. Fifteen fish from each temperature experiment ( 5 from each salinity treatment) were chosen randomly, rinsed in de-ionized water, and frozen at $-80^{\circ} \mathrm{C}$. These fish were freeze-dried at $-80^{\circ} \mathrm{C}$ to a constant weight ( 48 to $72 \mathrm{~h}$ ), and dry weights determined for dry weight-specific feeding and growth rates.

Data analysis. Daily specific growth rate $(G)$ of each fish in the feeding/growth experiments was calculated as: $G=\left[\left(\operatorname{Ln} W t_{\mathrm{f}}-\operatorname{Ln} W t_{\mathrm{i}}\right) / d \times 100\right] ;$ where $W t_{\mathrm{f}}=$ final wet weight, $W t_{1}=$ initial wet weight, and $d=$ number of feeding days. Mean daily specific growth rate was then calculated for each temperature and salinity treatment.

Daily specific ad libitum feeding rates were calculated in terms of wet weight $(\mathrm{g}$ ww consumed/g wet body weight); dry weight (mg dw consumed/g dry body weight); organic matter (mg organic matter consumed/g dw fish); and energy (Joules consumed/g dw fish). Daily body weights of fish were calculated from initial and final weights according to the exponential growth model: $W t=a \mathrm{e}^{G t}$; where $W t=$ weight ( $w w$ or dw), $a=$ initial weight, $G=$ daily specific growth rate, and $t=$ time in days (Ricker 1979). Mean daily specific feeding rate for each fish over the $10 \mathrm{~d}$ period was calculated, and then the mean daily specific feeding rate for each temperature and salinity treatment was determined.

Assimilation efficiency $(A E)$ was calculated for each fish according to the following formulae:

$$
\begin{aligned}
\text { Total } A E=\left[1-\left(\frac{\% \text { ash in mysids }}{\% \text { ash in feces }}\right)\right] \times 100 \% \\
\text { Organic } A E=\left[1-\left(\frac{\% \text { ash in mysids }}{\% \text { ash in feces }}\right) \times\right. \\
\left.\left(\frac{\% \text { organic in feces }}{\% \text { organic in mysids }}\right)\right] \times 100 \%
\end{aligned}
$$

Mean assimilation efficiencies were then calculated for each temperature and salinity treatment.

Gross growth efficiency $\left[K_{1}=\right.$ fish weight gain $(\mathrm{g}) /$ prey biomass consumed $(\mathrm{g})$ ], and net growth efficiency 
$\left[K_{2}=\right.$ fish weight gain $(\mathrm{g}) /$ prey biomass assimilated $\left.(\mathrm{g})\right]$ were also calculated for each fish. Means for each temperature and salinity treatment were then determined.

Mean feeding rates, growth rates, assimilation efficiencies, $K_{1}$, and $K_{2}$ were compared among temperature and salinity treatments using a 2-way ANOVA $(\mathrm{p}<0.05)$ and Tukey's multiple comparison tests ( $\mathrm{Zar}$ 1984). All means are reported \pm 1 standard deviation.

\section{RESULTS}

\section{Field collection of post-larvae and early juveniles}

Plankton tows caught the first post-larval summer flounder $(10 \mathrm{~mm}$ TL) entering the estuary during the second week of November 1989. A total of 3 fish were caught in November, 6 in December, 1 in late January, 9 in February and 1 in March.

Summer flounder were first caught in 1990 seine
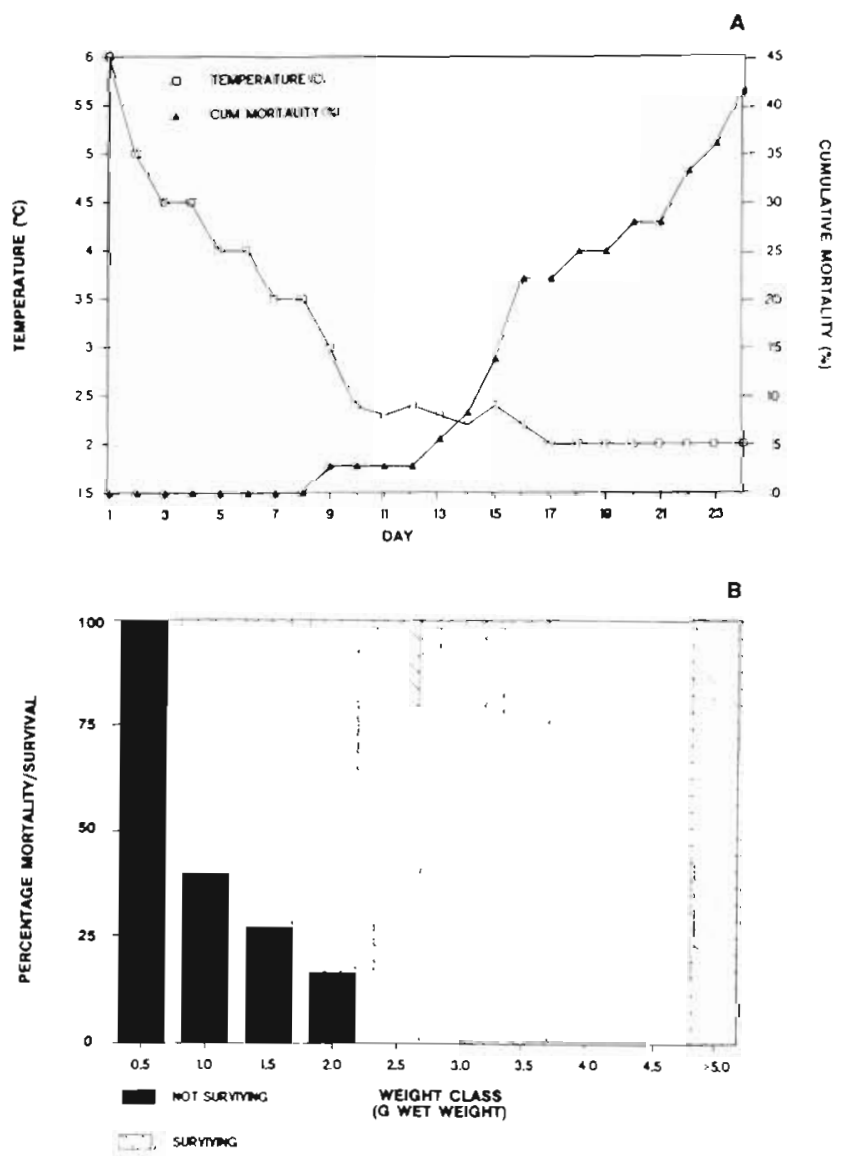

Fig. 1 Paralichthys dentatus. Mortality of juvenile summer flounder ( 40 to $70 \mathrm{~mm} \mathrm{TL}$ ) during the low temperature toler ance experiment. (A) Time course of cumulative mortality $(N=36$ on Day 1). (B) Frequency histogram of size-specific mortality after exposure to temperatures $\leq 3^{\circ} \mathrm{C}$ for $16 \mathrm{~d}$ collections on March 9 (14 fish, 12 to $14 \mathrm{~mm} \mathrm{TL).} \mathrm{Fish}$ were caught in seine collections at water temperatures from 2.9 to $21^{\circ} \mathrm{C}$ and salinities of 24 to $30 \%$. Seines collected the largest numbers of fish throughout May and June (ca 20 per $1000 \mathrm{~m}^{2}$ ). Total length of fish in the field increased rapidly, ranging between 15 to $20 \mathrm{~mm}$ in late April and 40 to $65 \mathrm{~mm}$ in the first week of June

\section{Survival at low temperatures}

The first mortality in the low-temperature tolerance experiment occurred at $3^{\circ} \mathrm{C}$, and total mortality was


Fig. 2. Paralichthys dentatus. (A) Mean weight-specific feeding rate, $(B)$ specific growth rates $(G)$, and (C) gross growth efficiency $\left(K_{1}\right)$ of juvenile summer flounder at 5 experimental temperatures. Error bars are $95 \%$ Tukey's multiple comparison intervals; $\mathrm{N}=30$ for each point except where indicated 
$42 \%$ following exposure to temperatures of 2 to $3{ }^{\circ} \mathrm{C}$ for $16 \mathrm{~d}$ (Fig. 1A). Mortality was size-specific, with the smallest fish experiencing the highest mortality rates (Fig. 1B). There was $100 \%$ mortality of fish less than $1 \mathrm{~g}$ wet weight $(50 \mathrm{~mm} \mathrm{TL})$, while all fish larger than $2.5 \mathrm{~g}(65 \mathrm{~mm} \mathrm{TL})$ survived temperatures $<2.5^{\circ} \mathrm{C}$ for the $2 \mathrm{wk}$ period. $\chi^{2}$ analysis revealed no significant effect of salinity on mortality in the low temperature tolerance experiment $(\mathrm{p}>0.75)$. The low temperature experiment at $2{ }^{\circ} \mathrm{C}$ with larger fish resulted in no mortalities, but all fish lost weight over the course of the experiment (mean weight loss $=0.77 \mathrm{~d}^{-1}$ ).

\section{Feeding rate}

Two-way ANOVA on mean daily specific ad libitum (wet weight) feeding rates showed no interaction of temperature and salinity, and no salinity effects, but revealed a significant temperature effect $(p<0.001)$. Although mean feeding rate increased from 1.04 to $4.07 \%$ body wt $\mathrm{d}^{-1}$ between 2 and $10^{\circ} \mathrm{C}$, these rates were not statistically different from one another (Fig. 2A). Mean feeding rate at $14{ }^{\circ} \mathrm{C}(12.31 \%$ body wt $\mathrm{d}^{-1}$ ) was significantly higher than at lower temperatures, and was 3 times that at $10^{\circ} \mathrm{C}$. Feeding rate at $18{ }^{\circ} \mathrm{C}\left(24.08 \% \mathrm{~d}^{-1}\right)$ was nearly twice the rate at $14{ }^{\circ} \mathrm{C}$.

Wet weight/dry weight ratios of fish and mysids did not differ among treatment groups, resulting in the following relationship between wet weight and dry weight specific feeding rates (SFR): $\mathrm{SFR}_{\mathrm{dry}}=\mathrm{SFR}_{\text {wet }}$ ' 1.98. Organic content of mysids was 762 ( \pm 3 ) $\mathrm{mg}$ organic material $\mathrm{g}^{-1} \mathrm{dw}$ and energy content was 20.05 $( \pm 0.59) \mathrm{J} \mathrm{g}^{-1} \mathrm{dw}$. These values can be used to calculate daily feeding rates at each temperature in terms of organic matter and energy according to the following relationships: $\mathrm{SFR}_{\text {organic }}=\mathrm{SFR}_{\text {wet }} \times 384.8 ; \mathrm{SFR}_{\text {Joules }}=$ $\mathrm{SFR}_{\text {wet }} \times 10.13$.

\section{Assimilation efficiency}

Two-way ANOVA showed no significant effects of temperature or salinity on total assimilation efficiency (mean $=60.3 \pm 0.3 \%)$ or organic assimilation efficiency $($ mean $=79.1 \pm 0.8 \%)$.

\section{Growth rate}

Two-way ANOVA on specific growth rate revealed a marginally significant interaction of temperature and salinity ( $p=0.043)$. No significant effect of salinity was observed $(p=0.084)$. Temperature had a significant

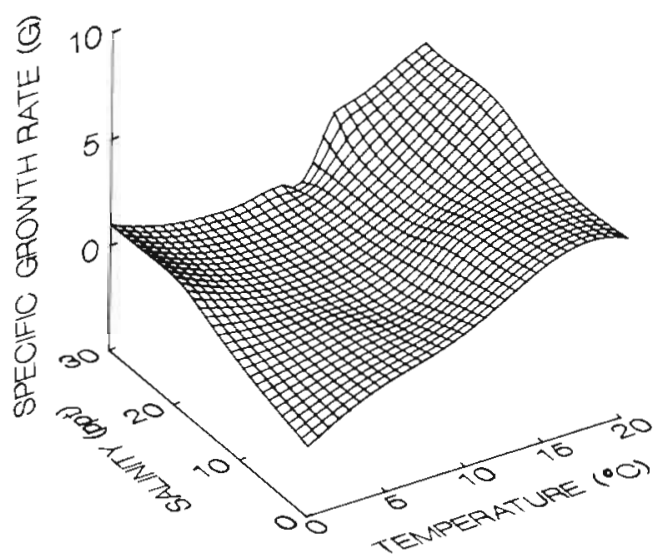

Fig. 3. Paralichthys dentatus. Response-surface diagram of juvenile summer flounder growth rate in relation to temperature and salinity. Two-way ANOVA revealed a marginally significant interaction between temperature and salinity $(p=0.043)$, but no independent salinity effect

effect on specific growth rate $(p<0.001)$ and growth rate showed a relationship to temperature similar to that of feeding rate (Figs. $2 \mathrm{~B} \& 3$ ). Mean growth rates were not significantly different between 2 and $10^{\circ} \mathrm{C}$ (mean $=0.14 \mathrm{~d}^{-1} ; 0.05 \mathrm{~mm} \mathrm{~d}^{-1}$ ), indicating that fish maintain or lose weight at temperatures below $10^{\circ} \mathrm{C}$. Additionally, mean growth rates at 2 and $6{ }^{\circ} \mathrm{C}$ were not significantly different from $0(1$-tailed $t$-test, $\mathrm{p}>0.05)$. Mean growth rate at $14^{\circ} \mathrm{C}$ was $2.3 \mathrm{~d}^{-1}\left(0.24 \mathrm{~mm} \mathrm{~d}^{-1}\right)$, 6 times the rate at $10^{\circ} \mathrm{C}$. Mean growth rate at $18^{\circ} \mathrm{C}$ was $3.8 \mathrm{~d}^{-1}\left(0.7 \mathrm{~mm} \mathrm{~d}^{-1}\right)$.

\section{Growth efficiency}

Mean $K_{1}$ and $K_{2}$ were not significantly affected by salinity, nor was there a significant interaction between temperature and salinity. Mean growth efficiency at $6{ }^{\circ} \mathrm{C}(-23.2 \%)$ was significantly lower than at 14 and $18^{\circ} \mathrm{C} \quad(18.4$ and $22.1 \%$, respectively), primarily because the mean growth rate was negative at $6{ }^{\circ} \mathrm{C}$ (Fig. 2C). No significant differences were found among the other temperature treatments, but growth efficiency values were highly variable. The relationship of $K_{2}$ to temperature was identical to that of $K_{1}$ since assimilation efficiency was not different among temperatures.

\section{Water temperatures recorded in nursery areas}

Bottom water temperatures recorded at the collection site of post-larvae and demersal juveniles (Indian River Bay, Delaware), and at Great Bay, New Jersey in winter $1989-1990$ were below 2 to $3{ }^{\circ} \mathrm{C}$ for 3 to $4 \mathrm{wk}$ 

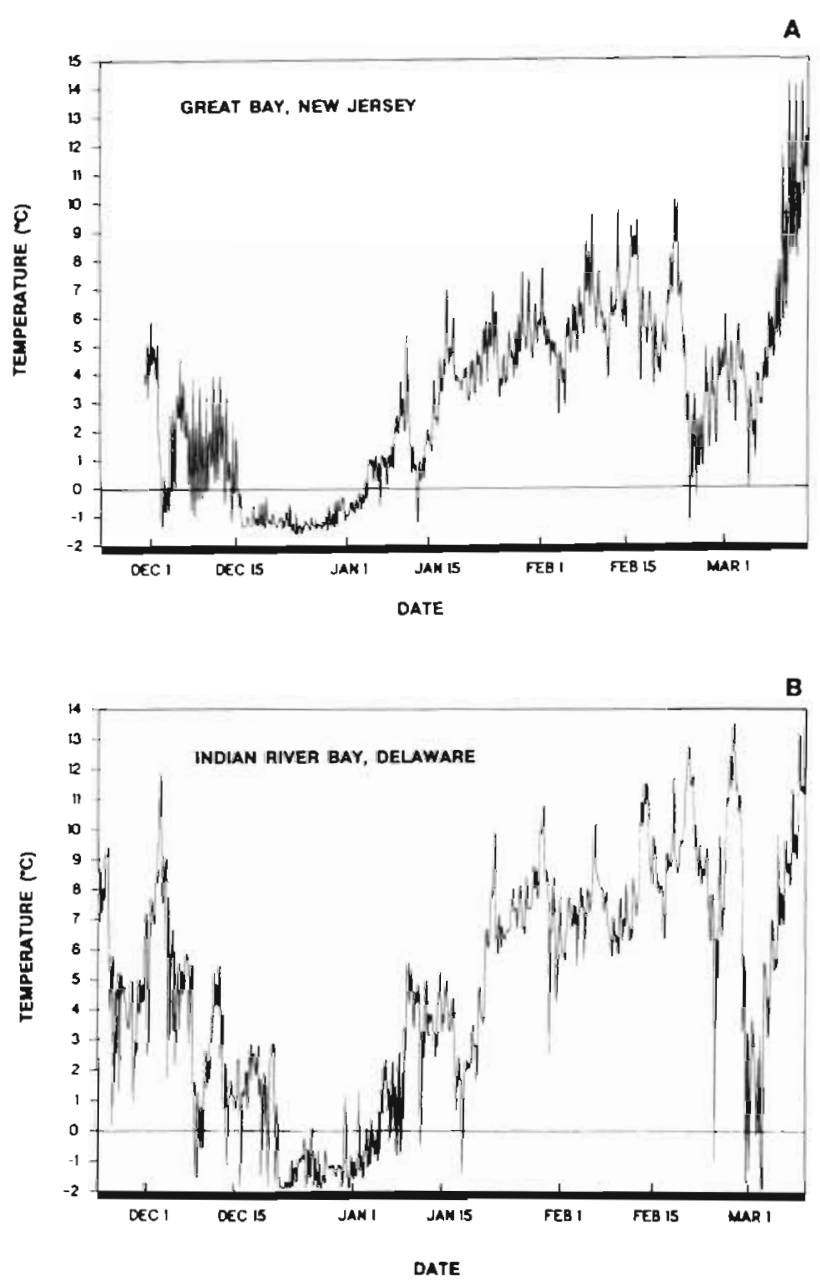

Fig. 4. Bottom water temperature in (A) a tidal creek off Great Bay, New Jersey and (B) Indian River Bay, Delaware from November 25, 1989 through March 10, 1990. Temperatures are $2 \mathrm{~h}$ means of measurements recorded at $20 \mathrm{~min}$ intervals

during December and January (Fig. 4). Temperatures did not remain above $10^{\circ} \mathrm{C}$ until after mid-March. Although the same pattern of temperature fluctuations was observed at both sites, temperatures at the Great Bay site were generally lower than those in Indian River Bay. Both sites showed large variability in water temperatures over tidal and diel time frames.

\section{DISCUSSION}

\section{Importance of northern estuaries as nursery grounds} for juvenile summer flounder

Many studies have reported summer flounder from estuaries in the north/central MAB (Poole 1961, Pearcy \& Richards 1962, Pacheco \& Grant 1973, Smith 1973, Ecological Analysts 1976, Able et al. 1990, Szedlmayer et al. in press). Smith (1973) reported high concentrations of summer flounder eggs and larvae on the continental shelf in the northern MAB during sampling in 1965-1966, with the center of abundance off New Jersey and New York. Able et al. (1990) confirmed that extensive spawning occurred in 1979-1985 as far north as Cape Cod, and reported the largest collection of eggs and larvae between New York and Massachusetts. Collections of post larvae and early juveniles from estuaries in Delaware and New Jersey (Pacheco \& Grant 1973, Ecological Analysts 1976, Able et al. 1990, Szedlmayer et al. in press, field collections of this study) have led to the conclusion that northern/central MAB estuaries are more important nursery grounds for juvenile summer flounder than previously thought. Post-larvae and juveniles occur in cold $\left(<10^{\circ} \mathrm{C}\right)$ waters in northern estuaries as shown by temperature measurements in this study and others. Bottom water temperatures recorded in juvenile summer flounder nurseries in the present study were below 2 to $3^{\circ} \mathrm{C}$ for 3 to 4 wk (Fig. 3). Pacheco \& Grant (1973) caught postlarval summer flounder in winter flood-tide plankton tows at Indian River Inlet, Delaware (the source of oceanic water input to the collection site of this study) at water temperatures $<3{ }^{\circ} \mathrm{C}$. Post-larval summer flounder have been caught in plankton tows near Roosevelt Inlet, Delaware (this study) and in Great Bay, New Jersey (Able et al. 1990) throughout the coldest months. In addition, juvenile summer flounder have been collected at temperatures as low as $2.1^{\circ} \mathrm{C}$ in estuaries as far south as Virginia (Wyanski 1988).

\section{Effects of low temperature on survival in northern estuaries}

The present results indicate that early juvenile summer flounder can survive water temperatures as low as $3{ }^{\circ} \mathrm{C}$ for several weeks, and some can survive temperatures as low as $2^{\circ} \mathrm{C}$ for up to $8 \mathrm{~d}$. This study found one major period of about 25 consecutive days during December (1989) and January (1990) when water temperatures were below $3{ }^{\circ} \mathrm{C}$ (Fig. 4). Pacheco \& Grant (1973) reported periods of 17 to 35 consecutive days each year (1958 to 1961), in December, February or March, when water temperatures at Indian River Inlet, Delaware were $<3^{\circ} \mathrm{C}$. These data suggest that mortality due to extremely low temperatures in northern estuaries can occur during a 2 to 4 wk critical period, between December and March, when water temperatures are below the lower lethal limit.

Post-larval summer flounder appear to immigrate into northern MAB estuaries at low densities over a protracted season from October through May, although pulses occur at varying times each year (DeSylva et al. 
1962, Pacheco \& Grant 1973, Ecological Analysts 1976, Wyanski 1988, Able et al. 1990, Szedlmayer et al. in press, this study). These pulses frequently occur during the coldest months of winter (DeSylva et al. 1962, Pacheco \& Grant 1973, Ecological Analysts 1976). Wyanski (1988) caught post-larvae 13 to $20 \mathrm{~mm}$ TL entering Virginia estuaries from early November to late April, and recorded highest densities in March and April. Able et al. (1990) noted peak influxes of 10 to $20 \mathrm{~mm}$ (TL) individuals from October to December and a second, smaller influx from late March to May for the period 1977 to 1985. Post-larval summer flounder appear inshore earlier in years with mild winters than in years with severe winters, suggesting the potential importance temperature may have on early stages (Cain \& Dean 1976, Bozeman \& Dean 1980).

Timing of discrete periods of lethal temperature minima may interact with the timing of post-larval arrival into northern $\mathrm{MAB}$ estuaries to affect survival, and potentially recruitment success, of young summer flounder. Since growth is $\leq 0$ at temperatures $<10^{\circ} \mathrm{C}$, immigrating post-larvae could remain 10 to $14 \mathrm{~mm}$ TL throughout the winter, and exposure to the annual period of temperature minima $<2.5{ }^{\circ} \mathrm{C}$ would presumably result in substantial mortality if it lasted $>8 \mathrm{~d}$. If immigration rate is assumed to be constant from November through April, the occurrence of lethal low temperatures in December would affect relatively few of the total year-class of immigrants, since only those fish arriving prior to the cold period would be exposed to low lethal temperatures. However, if that period of low lethal temperatures were to occur in March, the resulting mortality could be much higher, simply because more fish would be inshore at that time of year.

The occurrence of several, short-duration $(<8 \mathrm{~d})$ cold periods may have a less significant effect on mortality, since the present results suggest that substantial mortality occurs only after prolonged ( $>8 \mathrm{~d}$ ) exposure to temperatures $<3^{\circ} \mathrm{C}$. The survival of larger fish at $2{ }^{\circ} \mathrm{C}$ may suggest that mortality of smaller fish resulted from starvation. However, acute exposure to temperatures $<2{ }^{\circ} \mathrm{C}$ may also result in high mortality. There are data which suggest high mortality of juvenile summer flounder in Chesapeake Bay at 0.5 to $1.5^{\circ} \mathrm{C}$ due to an impaired immune response (Burreson \& Zwerner 1982, Sypek \& Burreson 1983, Burreson \& Zwerner 1984). More data are needed on acute low temperature mortality of post-larval/early juvenile summer flounder.

Juveniles which arrive in northern MAB estuaries in the fall, sufficiently in advance of winter temperature minima, may be able to grow past a lower critical size, thus increasing survival. Our laboratory results suggest that fish would have to reach sizes greater than $1 \mathrm{~g}$ (ca
$50 \mathrm{~mm} \mathrm{TL}$ ) in order to increase survival at extremely low temperatures. Collections summarized by Able et al. (1990) suggest that this early growth prior to winter temperature minima may occur in some years.

Research on low temperature tolerance of bothids is scarce. Johns et al. (1981) found that larval summer flounder held at $5{ }^{\circ} \mathrm{C}$ did not grow, and did not survive past yolk-sac absorption. Our laboratory experiments on juveniles showed $100 \%$ survival at $6{ }^{\circ} \mathrm{C}$, and Edwards et al. (1962) reported live catches of adult summer flounder at water temperatures of $6.6^{\circ} \mathrm{C}$, supporting the concept that older fish have an increased tolerance to low temperatures. Observations of postlarval summer flounder held at ambient temperatures in New Jersey support our laboratory results that the lower lethal temperature is 2 to $3^{\circ} \mathrm{C}$ (Szedlmayer et al. in press). Juveniles of the congener Paralichthys lethostigma, which occurs farther south, were found to cease feeding after $1 \mathrm{~d}$ at $2{ }^{\circ} \mathrm{C}$, and died after $2 \mathrm{~d}$ at $2{ }^{\circ} \mathrm{C}$ (acclimated at $1{ }^{\circ} \mathrm{C} \mathrm{d}^{-1}$ ) (Prentice 1989), suggesting that this species has somewhat less tolerance for low temperatures.

Although the summer flounder population is considered a unit stock by fisheries managers (Mid-Atlantic Fishery Management Council 1987), there is some evidence to indicate that 2 stocks may exist and contribute to the fishery in the MAB (see Mid-Atiantic Fishery Management Council 1988). A northern or offshore stock may occur north of Cape Hatteras and a southern or 'trans-Hatteras/inshore' stock may occur primarily south of Cape Hatteras but move northward to inshore waters of the MAB during the summer. Different physiological responses may exist in fish from northern and southern stocks, but the question of multiple stocks is still unclear.

\section{Feeding rate and assimilation efficiency}

Ad libitum feeding rates increased with temperature, ranging from $1.04 \% \mathrm{~d}^{-1}$ at $2{ }^{\circ} \mathrm{C}$ to $24 \% \mathrm{~d}^{-1}$ at $18^{\circ} \mathrm{C}$. These rates are in agreement with estimates for juveniles from North Carolina, which had predicted ad libitum feeding rates of ca $23 \% \mathrm{~d}^{-1}$ at $18{ }^{\circ} \mathrm{C}$ (Peters \& Angelovic 1971). Edwards et al. (1969) found that juvenle plaice Platichthys platessa consumed 5 to $8 \%$ of their body weight $\mathrm{d}^{-1}$ at $10^{\circ} \mathrm{C}$, close to our value of $4 \% \mathrm{~d}^{-1}$ at $10^{\circ} \mathrm{C}$ for juvenile summer flounder.

Our data demonstrate that the assimilation efficiency of juveniles was high $($ mean $=60.3 \%$ ) over a range of temperatures and salinities. Johns et al. (1981) reported that yolk conversion efficiencies of summer flounder larvae were not significantly different from each other between 11 and $21^{\circ} \mathrm{C}$, and Johns \& Howell (1980) found that summer flounder larvae 
raised at 16 and $21^{\circ} \mathrm{C}$ had similar yolk conversion efficiencies, suggesting that the physiological mechanisms involved are able to compensate for temperature changes.

\section{Growth in northern estuaries}

Although there was no mortality above $3^{\circ} \mathrm{C}$, growth rates were not significantly different from 0 below $10^{\circ} \mathrm{C}$. Water temperatures typically do not reach $10^{\circ} \mathrm{C}$ in Delaware's Inland Bays in the spring until late April (Pacheco \& Grant 1973, J. Davis pers. comm., this study). Since metamorphosing juveniles enter estuaries throughout the late fall and winter, it is likely that fish which survive periods of low temperature $>2$ to $3^{\circ} \mathrm{C}$ do feed, but do not grow until late April. All juveniles caught in our seine collections at the end of April were 15 to $20 \mathrm{~mm}$ TL.

Since mortality due to predation is often size-dependent in fishes (Folkvord \& Hunter 1986), the extended period of time spent at small sizes may increase vulnerability to predation. A small degree of early growth may be important to reduce early mortality (Houde 1989). Because growth rates increase rapidly with termperature above $10^{\circ} \mathrm{C}$, the timing of occurrence of water temperatures greater than $10^{\circ} \mathrm{C}$ in the spring may be important to predator-induced mortalities in northern estuaries. Juvenile plaice $<30 \mathrm{~mm}$ TL are preyed upon heavily by brown shrimp Crangon crangon in the Wadden Sea, but $C$. crangon are unable to catch plaice $>30 \mathrm{~mm}$ (Van der Veer \& Bergman 1987). Plaice $<50 \mathrm{~mm}$ TL are preyed upon by the shore crab Carcinus maenas, but this crab is unable to prey on plaice $>50 \mathrm{~mm}$ (Van der Veer \& Bergman 1987). Species similar to these (e.g. Crangon septemspinosa and Callinectes sapidus), as well as many species of adult fish, appear in large numbers in MAB estuaries in early spring (Price 1962, Smith 1987), and are potential predators of juvenile summer flounder.

Growth rates of juvenile summer flounder at temperatures above $10^{\circ} \mathrm{C}$ in this study are similar to those found in other laboratory studies. Predicted growth rates of juveniles from North Carolina at $10{ }^{\circ} \mathrm{C}$ (at $20 \%$ ) were also close to 0 (Peters \& Angelovic 1971). Specific growth rates of North Carolina juveniles were 5 and $10 \% \mathrm{~d}^{-1}$, at 15 and $20^{\circ} \mathrm{C}$, respectively (Peters \& Angelovic 1971), somewhat higher than our measured growth rates of 2.4 and $3.9 \% \mathrm{~d}^{-1}$ at 14 and $18^{\circ} \mathrm{C}$. However, Peters \& Angelovic (1971) held fish at 10 to $15^{\circ} \mathrm{C}$ with no acclimation to experimental temperatures, and the duration of their experiments was only 4 to $7 \mathrm{~d}$.

Water temperatures in MAB estuaries are above $20^{\circ} \mathrm{C}$ for much of the summer (i.e. June through Sep- tember), and growth rates at the highest temperature treatment of $18^{\circ} \mathrm{C}$ in the present study are probably much lower than growth in the field during the summer. Field observations suggest that age 0 summer flounder may grow up to $2 \mathrm{~mm} \mathrm{~d}^{-1}$, and may reach $280 \mathrm{~mm}$ TL by the end of their first summer (Able et al. 1990, Szedlmayer et al. in press).

\section{Growth efficiency $\left(K_{1}\right)$}

Although there was a general trend of increasing growth efficiency with increasing temperature, the only significant difference was between 6 and 14/ $18^{\circ} \mathrm{C}$. This difference resulted primarily from the mean growth rate at $6^{\circ} \mathrm{C}$ being negative. Our values of growth efficiency at 14 and $18^{\circ} \mathrm{C}$ were higher than those predicted for juvenile summer flounder from North Carolina at the same temperatures (Peters \& Angelovic 1971), suggesting that Delaware fish are better adapted for lower temperatures. Both studies found that growth efficiency was close to 0 at temperatures $\leq 10^{\circ} \mathrm{C}$ due to low growth rates, but the $K_{1}$ of Delaware fish increased to $18 \%$ at $14{ }^{\circ} \mathrm{C}$, while the $K_{1}$ of North Carolina fish was predicted to remain near 0 at $14^{\circ} \mathrm{C}$ (Peters \& Angelovic 1971). The predicted $K_{1}$ of North Carolina fish at $18^{\circ} \mathrm{C}$ was ca $20 \%$ (Peters \& Angelovic 1971), closer to our value of $22 \%$. Colman (1970) found that conversion efficiencies of early juvenile plaice increased with temperature, and were 19 to $24 \%$ at $16^{\circ} \mathrm{C}$.

\section{Importance of salinity to summer flounder distribution}

The present study found that salinity $(10$ to $30 \%$ ) had no significant effect on feeding, growth or survival of juvenile summer flounder. However, there was a slight interaction of temperature and salinity on growth rate, which suggested that fish have higher growth rates at high salinities and at high temperatures (Fig. 3). This agrees with the data from previous studies, but the test salinities in these other studies were primarily $\geq 20 \%$ (Peters \& Angelovic 1971, Deubler \& White 1962). There appears to be no significant physiological advantage or greater capacity for growth in waters of higher salinities, except perhaps at very high temperatures. Therefore, the reported distributions of juvenile summer flounder at salinities $>12 \%$ (see Rogers \& Van Den Avyle 1983) are probably the result of substrate and prey availability. Wyanski (1988) found that juvenile summer flounder prefer muddier substrate. especially in association with tidal creeks in salt marshes. 


\section{CONCLUSIONS}

Year-class strength of summer flounder has varied considerably over the past $40 \mathrm{yr}$, and commercial landings have fluctuated dramatically over the past $5 \mathrm{yr}$ (Mid-Atlantic Fishery Management Council 1988). Although larval mortality during inshore transport is a potential source of variability, subtle changes in environmental factors may have a larger impact on recruitment than episodic events such as transport displacement (Houde 1989). Because early juveniles remain inshore during their first winter and spring, variability of factors affecting their feeding, growth and survival during this time may have a large impact on recruitment success. The timing, duration and magnitude of winter temperature minima $\left(<3^{\circ} \mathrm{C}\right)$ may affect the total number of juveniles which survive the winter. Because growth rates are $\leq 0$ at temperatures $<10^{\circ} \mathrm{C}$, the duration of low winter temperatures $\left(3\right.$ to $\left.10^{\circ} \mathrm{C}\right)$ will dictate the length of time that juveniles remain at small (and more vulnerable) sizes, thus will affect survival. Similarly, small changes in the timing and duration of periods of water temperatures 10 to $14^{\circ} \mathrm{C}$ could have large effects on survival, since growth rates of juvenile summer flounder increase dramatically between 10 and $14{ }^{\circ} \mathrm{C}$. The annual contribution of new recruits from north/central $\mathrm{MAB}$ estuaries appears to be dependent on winter temperature regime, particularly on the magnitude and timing of temperature minima.

Acknowledgements. We are grateful to Anne Boettcher, Jami Montgomery, Martin Connaughton, and T Lankford for their help with seine collections, and to George Mayer for his advice on locating juvenile summer flounder We thank Andy Manus for making additional funds from the Delaware Sea Grant Program available for purchase of the recording temperature probes. Kelly Smith and Ken Able deployed the temperature probe in New Jersey and assisted in data analysis. We thank Pat Gaffney for helpful comments on statistics and for generating the response-surface diagram. We also thank students in the CMS 827 Topics in Fish Biology class for their helpful review and discussion of this manuscript. This research was sponsored by NOAA Office of Sea Grant, Department of Commerce, under grant No. NA85AA-DSG033 (Project No. R/F-2).

\section{LITERATURE CITED}

Able, K. W., Matheson, R. E., Morse, W. W., Fahay, M. P., Shepherd, G. (1990). Patterns of summer flounder (Paralichthys dentatus) early life history in the Mid-Atlantic Bight and New Jersey estuaries. Fish. Bull. U.S. 88: 1-12

Anthony, V. C., Fogarty, M. J. (1985). Environmental effects on recruitment, growth and vulnerability of Atlantic herring (Clupea harengus) in the Gulf of Maine Region. Can. J. Fish. Aquat. Sci. 42: 158-173

Bailey, K. M., Houde, E. D. (1989). Predation on eggs and larvae of marine fishes and the recruitment problem. Adv. Mar Biol. 25: 1-83
Bozeman, E. L., Dean, J. M. (1980). The abundance of estuarine larval and juvenile fish in a South Carolina intertidal creek. Estuaries 3: 89-97

Brett, J. R. (1979). Environmental factors and growth. In: Hoar, W. S., Randall, D. J., Brett, J. R. (eds.) Fish physiology, Vol. 8. Bioenergetics and growth. Academic Press, New York, p. 599-667

Brown, J. A., Pepin, P., Methuen, D. A., Somerton, D. C. (1989). The feeding, growth and behavior of juvenile cod, Gadus morhua, in cold environments. J. Fish Biol. 35: 373-380

Burreson, E. M. Zwerner, D. E. (1982). The role of host biology, vector biology, and temperature in the distribution of Trypanosoma bullocki infections in the lower Chesapeake Bay. J. Parasitol. 68: 306-313

Burreson, E. M., Zwerner, D. E. (1984). Juvenile summer flounder, Paralichthys dentatus, mortalities in the western Atlantic Ocean caused by the hemoflagellate Trypanosoma bullocki; evidence from field and experimental studies. Helgoländer Meeresunters. 37: 343-352

Cain, R. E., Dean, J. M. (1976). Annual occurrence, abundances and diversity of fish in a South Carolina intertidal creek. Mar Biol. 36: 369-379

Cech, J. J. Jr, Mitchell, S. J. (1984). Comparative growth of juvenile white sturgeon and striped bass: effects of temperature and hypoxia. Estuaries 7: 12-18

Colman, J. A. (1970). On the efficiency of food conversion of young plaice (Pleuronectes platessa). J. mar biol. Ass. U.K. 50: $113-120$

Daiber, F. C., Thornton, L. L., Tyrawski, J. M., Campbell, T G., Jones, D. R. (1975). A summary of the biological and hydrographic data for the Lewes-Rehoboth Bay area. A report to The Delaware State Planning Office by the College of Marine Studies, Univ. of Delaware Lewes

DeSilva, S. S., Perera, M. K. (1984). Digestibility in Sartherodon niloticus fry: effect of dietary protein level and salinity with further observations on variability in daily digestibility. Aquaculture 38: 293-306

DeSylva, D. P., Kalber, F. A., Schuster, C. N. (1962). Fishes and ecological conditions in the shore zone of the Delaware River Estuary, with notes on other species collected in deeper water Univ. of Delaware Marine Lab., Inform. Ser Pub. No. 5

Deubler, E. E. Jr (1958). A comparative study of the postlarvae of three flounders (Paralichthys) in North Carolina. Copeia 1958: 112-116

Deubler, E. E. Jr., White, J. C. (1962). The influence of salinity on growth of post-larvae of the summer flounder Paralichthys dentatus. Copeia 1962: 468-489

Ecological Analysts (1976). Ecological studies in the vicinity of the Indian River Power Plant for the period June 1974-August 1976. Ecological Analysts, Inc., Towson, MD. Prepared for Delmarva Power and Light Co., Wilmington, DE

Edwards, R. L., Livingston, R., Hamer, P. E. (1962). Winter water temperatures and an annotated list of fishes - Nantucket Shoals to Cape Hatteras: Albatross IIl Cruise No. 126. U.S. Fish and Wildlife Service Special Scientific Report, $397 \mathrm{pp}$

Edwards, R. R. C., Finlayson, D. M., Steele, J. H. (1969). The ecology of 0-group plaice and common dabs in Loch Ewe. II. Experimental studies of metabolism. J. exp. mar. Biol. Ecol. 3: 1-17

Folkvord, A., Hunter, J. R. (1986). Size-specific vulnerability of northern anchovy, Engraulis mordax, larvae to predation by fishes. Fish. Bull. U.S. 84 : 859-869 
Holt, J., Godbout, R., Arnold, C. R. (1981). Effects of temperature and salinity on egg hatching and larvai survival of red drum Sciaenops ocellata. Fish. Bull. U.S. 79: 569-573

Houde, E. D. (1987). Fish early life dynamics and recruitment variability. Am. Fish. Soc. Symp. 2: 17-29

Houde, E. D. (1989). Subtleties and episodes in the early life of fishes. J. Fish Biol. 35A: 29-38

Houde, E. D., Taniguchi, A. K. (1979). Laboratory culture of marine fish larvae and their role in marine environmental research. In: Jacoff, F. S. (ed.) Proceedings of a symposium on advances in marine environmental research. U.S. Environmental Protection Agency, Washington D.C., p. $176-205$

Houde, E. D., Taniguchi, A. K. (1981). Marine fish larvae growth and survival, effects of density-dependent factors: spotted sea trout (Cynoscion nebulosus) and lined sole (Achirus lineatus). Rept. to U.S. Env. Prot. Ag. Environmental Research Lab., Narragansett, RI. $66 \mathrm{pp}$.

Hunter, J. R. (ed.) (1976). Report of a colloquium on larval fish mortality studies and their relation to fishery research, Jan 1975. NOAA Tech. Rep. NMFS CIRC-395, 5 pp.

Johns, D. M., Howell, W. H. (1980). Yolk utilization in summer flounder (Paralichthys dentatus) embryos and larvae reared at two temperatures. Mar Ecol. Prog. Ser. 2: 1-8

Johns, D. M., Howell, W. H., Klein-MacPhee, G. (1981). Yolk utilization and growth to yolk-sac absorption in summer flounder (Paralichthys dentatus) larvae at constant and cyclic temperatures. Mar. Biol. 63: 301-308

Kinne, O. (1960). Growth, food intake and food conversion in a euryplastic fish exposed to different temperatures and salinities. Physiol. Zool. 33: 288-318

Lee, N. Y., Holt, G. J., Arnold, C. R. (1984). Growth of red drum larvae in the laboratory. Trans. Am. Fish. Soc. 113: $243-246$

May, R. C. (1974). Larval mortality in marine fishes and the critical period concept. In: Blaxter, J. H. S. (ed.) The early life history of fish. Springer-Verlag, New York, p. 3-19

McMullen, D. M., Middaugh, D. P. (1985). The effect of temperature and food density on survival and growth of Menidia peninsulae larvae (Pisces: Atherinidae). Estuaries 8: $39-47$

Mid-Atlantic Fisheries Management Council (1988). Fishery management plan for the summer flounder fishery. $157 \mathrm{pp}$. + Appendices and Attachments

Murawski, W S. (1970). Results of tagging experiments of summer flounder (Paralichthys dentatus) conducted in New Jersey waters from 1960-1967. New Jersey Dept. Envir. Prot. Bureau Fish. Misc. Rep. 5M. 52 pp.

Pacheco, A. L., Grant, G. C. (1973). Immature fishes associated with larval Atlantic menhaden at Indian River Inlet, Delaware, 1958-1961. In: Pacheco, A. L. (ed.) Proceedings of a Workshop on Egg, Larval and Juvenile Stages of Fish in Atlantic Coast Estuaries. Tech. Publ. no. 1, Nat. Mar. Fish. Serv., Highlands, New Jersey, p. 78-117

Pearcy, W. G., Richards, S. W. (1962). Distribution and ecology of fishes in the Mystic River Estuary, Connecticut. Ecology 43: $248-259$

Peters, D. S., Angelovic, J. W. (1971). Effect of temperature, salinity and food availability on growth and energy utilization of juvenile summer flounder, Paralichthys dentatus. In. Nelson, P. J. (ed.) Proceedings of the third national symposium on radioecology. U.S. Atomic Energy Commission, U.S. Department of Commerce, Springfield, Virginia, p. $545-554$

Phillipson, J. (1964). A miniature bomb calorimeter for small biological samples. Oikos 15: 130-139

Poole, J. C. (1961). Age and growth of the fluke in Great South
Bay and their significance to the sport fishery. N.Y Fish Game J. 8: 1-18

Poole, J. C. (1966). A review of research concerning summer flounder and needs for further study. N.Y Fish Game J. 13: 226-231

Powell, A. B., Schwartz, F. J. (1977). Distribution of paralichthid flounders (Bothidae: Paralichthys) in North Carolina Estuaries. Chesapeake Sci. 18: 334-339

Prentice, J. A. (1989). Low-temperature tolerance of southern flounder in Texas. Trans. Am. Fish. Soc. 118: 30-35

Price, Jr. K. S. (1962). Biology of the sand shrimp, Crangon septemspinosa, in the shore zone of the Delaware Bay region. Chesapeake Sci. 3: 244-255

Ricker, W. E. (1979). Growth rates and models. In: Hoar, W. S., Randall, D. J., Brett, J. R. (eds.) Fish physiology, Vol. 8. Bioenergetics and growth. Academic Press, New York, p. $677-743$

Rogers, S. G., Van Den Avyle, M. J. (1983). Species profiles: life histories and environmental requirements of coastal fishes and invertebrates (South Atlantic) - summer flounder. U.S. Dept of the Interior, U.S. Fish and Wildife Servicer; U.S. Army Corps of Engineers

Schwartz, F. J. (1980). Food analyses of selected fishes captured in Cape Fear Estuary and adjacent Atlantic Ocean, NC., 1973-1978. Institute of Marine Sciences, Univ. of North Carolina, Moorehead City

Shelbourne, J. E. (1964). The artificial propagation of marine fish. Adv. mar. Biol. 2: 1-83

Sissenwine, M. P. (1984). Why do fish populations vary? In: May, R. (ed.) Exploitation of marine communities. Springer-Verlag, Berlin, p. 59-94

Smith, P. E. (1985). Year-class strength and survival of 0-group clupeids. Can. J. Fish. Aquat. Sci. 42 (suppl. 1): 69-82

Smith. R. W. (1987). Marine fish populations in Delaware Bay. Delaware Division of Fish and Wildlife, Dover, Delaware, project \# F-34-R. 24 pp

Smith, W. G. (1973). The distribution of summer flounder, Paralichthys dentatus, eggs and larvae on the continental shelf between Cape Cod and Cape Lookout, 1965-1966. Fish. Bull. U.S. 71. 527-535

Stocker, M., Haist, V (1984). Environmental variation and recruitment of Pacific Herring (Clupea harengus pallus) in the Strait of Georgia. Can. J. Fish. Aquat. Sci. 42: 174-180

Sypek, J. P.. Burreson, E. M. (1983). Influence of temperature on the immune response of juvenile summer flounder, Paralichthys dentatus, and its role in the elimination of Trypanosoma bullocki infections. Dev. comp. Immunol. 7: 277-280

Szedimayer, S. T., Able, K. W., Roundtree, R. A. (in press). Summer flounder growth and temperature induced mortality during the first year in New Jersey. Copeia

Taniguchi, A. K. (1981). Survival and growth of larval spotted seatrout (Cynoscion nebulosus) in relation to temperature, prey abundance and stocking density. Rapp. P. v. Réun. Cons. int. Explor. Mer 178: 507-508

Taniguchi, A. K. (1982). Growth efficiency estimates for laboratory reared larval spotted seatrout fed microzooplankton or rotifers. In. Bryan, C. F., Conner, J. V., Truesdale, F. M. (eds.) Proceedings of the fifth annual larval fish conference. Louisiana State University, Cooperative Fishery Research Unit, Baton Rouge, p. 6-11

Uphoff, J. H. Jr (1989). Environmental effects on survival of eggs, larvae and juveniles of striped bass in the Choptank River, MD. Trans. Am. Fish. Soc. 118: 251-263

Van der Veer, H. W., Bergman, M. J. N. (1987). Predation by crustaceans on a newly settled 0-group plaice Pleuronectes platessa population in the Western Wadden Sea. Mar. Ecol. Prog. Ser 35: 203-215 
Warren, C. E., Davis, G. E. (1967). Laboratory studies on the feeding, bioenergetics and growth of fish. In: Gerking, S. D. (ed.) The biological basis of freshwater fish production. Blackwell Sci. Publ., London, p. 175-214

Weatherley, A. H., Gill, H. S. (1987). The biology of fish growth. Academic Press, Harcourt Brace Jovanovich, London

White, D. B., Stickney, R. R. (1973). A manual of flatfish rearing

This article was submitted to the editor
Georgia Marine Science Center, University system of Georgia, Tech. Rep. Series No. 73-7 Skidaway Is., Georgia

Wyanski, D. M. (1988). Depth and substrate characteristics of age 0 summer flounder (Paralichthys dentatus) habitat in Virginia estuaries. M. A. thesis, School of Marine Science, The Coliege of William and Mary, Virginia

Zar, J. H. (1984). Biostatistical analysis. Prentice Hall, Englewood Cliffs, NJ

Manuscript first received: August 15, 1990

Revised version accepted: March 19, 1991 